\title{
Criminal Code Policy in The Effort of Corruption Prevention in Institutions Regional Disaster Management Agency
}

\author{
Masyhadi Irfani ${ }^{1}$ and Ira Alia Maerani ${ }^{2}$
}

Abstract. Settings on the Crime of corruption in the procurement of goods and services defined in the Criminal Code as well as in Act Corruption today. However, there are still weaknesses contained in the Anti-Corruption Act today, one about the formulation of minimum criminal sanctions, which do not formulate sentencing guidelines to implement this minimum criminal threats.

Corruption that has grown and occurs systemically and widespread must be done explicitly countermeasures to combat it. Corruption need severe sanctions (the imposition of the death penalty if necessary) in addition to confiscation of the wealth gained from corruption. Cooperation of various parties must be improved so that the law enforcement process runs with orderly and appropriate procedures, so that the perpetrators of criminal sanctions in kind (so that these sanctions have a deterrent effect) and eventually become a member of the public good and useful.

Some issues regarding the criminal system that it is still in need of repair in the future is to be considered in order to create legislation that is even better. In 2018 the concept of the Criminal Code has been no formulation of the articles related to the criminal system that specifically regulates the crime of corruption by local officials, only qualifying offense of corruption that meet the elements of the subject that is a local official.

Keywords: Legal Policy; Corruption.

\section{Introduction}

Observing the development of corruption, both in terms of quantity and in terms of quality, it is no exaggeration to say that corruption in Indonesia is not an ordinary crime but is a very unusual crime (extraordinary crime). Further, when examined from the side effects and the negative impact that is very destructive to the lives of people in Indonesia since the New Order government to date, it is clear that acts of corruption constitute the deprivation of economic and social rights of the people of Indonesia. ${ }^{3}$

As a sovereign country, Indonesia has the noble ideals of creating general welfare is the main foundation for any policy-making, including legislative policy to constantly seek to improve people's lives which is a constitutional right of every citizen of Indonesia. However, these goals can be hampered by corruption is growing very fast,

\footnotetext{
${ }^{1}$ Student of Master of Law, Universitas Islam Sultan Agung Semarang and Members of the Indonesian National Police (Polri), Email: masyadi85090747@gmail.com

${ }^{2}$ Faculty of Law Universitas Islam Sultan Agung

${ }^{3}$ Mien Rukmini, Aspek Hukum Pidana dan Kriminologi (Sebuah Bunga Rampai ), penerbit PT Alumni, Bandung, 2006, p.111
} 
even damage the joints of the nation, and not only financial harm or state economy, but damage the economy of the people, as well as being a threat to national and international stability. It is necessary for criminal law policy, especially regarding corruption, since it concerns focused on two main points, namely how the legal policies of corruption legislation in force at the moment and that will come.

The development of corruption in Indonesia is still relatively high, while its eradication is still very slow, Romli Atmasasmita, stated that, Corruption in Indonesia is already a flu virus that spreads throughout the body of government since the 1960s. Eradication measures are still halting until now. ${ }^{4}$ Further, he said that corruption also related to power due to the power authorities could abuse their power for personal interests, family and cronies. ${ }^{5}$

Based on the foregoing, the Indonesian government worth more incentive to tackle corruption, said menanggulanglebih emphasize we will be an action that has occurred (repressive), like cutting the grass, after being cut and then grew thick again, that corruption, kitamelakukan eradication of corruption means the offense is already implemented, because if it has not been done, we also can not know it was corruption or not.

Based on the problems described above, the authors are interested in doing research in the form of legal writing and discuss it in the form of a thesis entitled "Criminal Code Policy In The Effort of Corruption Prevention In Institutions Regional Disaster Management Agency".

This research aims to 1) To know the criminal law policy of the corruption in Institutions Regional Disaster Management Agency Kudus District; 2)To know the law enforcement efforts in combating corruption in Institutions Regional Disaster Management Agency Kudus District; 3) To know criminal law policy in an effort to eradicate corruption in the framework of criminal law reform in Indonesia.

\section{Research Methods}

The method used is qualitative analysis, namely data obtained through fieldwork and research literature then arranged systematically, and then analyzed qualitatively to achieve clarity issues to be discussed. The data is then analyzed using a theoretical and interpretive positive law which has been poured and then deductively conclude to address existing problems. ${ }^{6}$

\footnotetext{
${ }^{4}$ Romli Atmasasmita, Sekitar Masalah Korupsi,Aspek Nasional dan Aspek Internasional, Bandung, Mandar Maju, 2004, p. 1

${ }^{5}$ Ibid. p. 71

${ }^{6}$ Ibid, p.119
} 


\section{Results And Discussion}

\subsection{Development Policy In The Criminal Law Of Corruption In Institutions Regional Disaster Management Agency Kudus District}

Policy formulation Criminal Law in order to tackling corruption will come true has strived namely through the preparation of the draft Law on Corruption Eradication (Draft Corruption Bill 2010). The concept of the bill the Eradication of Corruption, UNCAC refers 2003. Basically, almost all of the provisions of corruption and other crimes related to corruption in the Corruption Eradication same bill with the Law on Combating Corruption.

Employee Disaster Management Agency (BPBD) is alleged to have embezzled Kudus Regency Central Java Governor grants amounting to Rp 456 million (four hundred and fifty six million) given to the agency. The grants received by the end of April 2014 for a death benefit to the victims of natural disasters and assistance to homes damaged by the disaster. Originally did not have a prejudice against his subordinates. The fund new checking after the diversion of aid from Jakarta Tohir Foundation for Rp190.000.000 (one hundred ninety million) for the 19 households who are victims of a landslide in the village of Menawan, District Gebog, Kudus.

Under the procedure, he said, to dilute the signature must be accompanied BPBDs head. The emergence of cases grant from the governor also do tracking. Because it does not know the number of the check, was forced to ask for assistance to Central Java province beforehand After knowing the number of the check, he said, BPBDs Kudus checks to Bank BRI Branch of Kudus the banks do not dare to provide information and welcome to report problems to the police because then entitled to ask for more detail the police were handling the case.

\subsection{Law Enforcement Efforts In Combating Corruption In Institutions Regional Disaster Management Agency Kudus District}

In an effort to eradicate corruption in order to reach the various modus operandi of financial irregularities country or state economy that is increasingly complex and sophisticated, then in the general explanation of Act No. 31 of 1999 in conjunction with Act No. 202001 Indak corruption is formulated such that it covers the deeds enrich himself or another person or a corporation unlawfully in terms of the formal and material. With the formulation, definition against the law (element against the law) in the corruption could also include acts of misconduct by a feeling of community justice must be prosecuted and convicted. This provision opens.

Corruption as in the explanation of Act No. 31, 1999 is classified as a criminal offense formal. This is to facilitate the verification mechanism, while still accommodating the values and sense of justice that diciderai by criminals. Formal criminal act is a criminal 
offense which is deemed to have (fully implemented) to do an act which is regulated by law. The formulation of a formal corruption, is very important in the process of evidence and the prosecution, which, despite the result of corruption has been returned to the state, the perpetrators of corruption can still be submitted to the court and remained convicted.

In order to achieve more effective to prevent and combat corruption, the legislation establishes specific minimum criminal sanctions, criminal penalties are higher and the threat of capital punishment is a criminal weighting. The law also establishes imprisonment for perpetrators of corruption that can not pay additional criminal restitution of state losses.

The law also expands the notion of public servants, which includes people who receive salaries or wages of the corporation who use capital or facilities from the state or society. The meaning of the facility are given preferential treatment in various forms, such as interest on the loan that is not fair, reasonable prices, granting exclusive licenses including the reduction of import duty or tax which is contrary to the legislation in force.

Another novelty is in the event of corruption are difficult to prove, it formed a joint coordination team by the Attorney General, being the investigations and prosecutions carried out in accordance with the legislation in force. It is intended to improve efficiency when handling corruption and also the protection of human rights of suspects and defendants. Some agencies or commissions set up to combat corruption, such as an ombudsman, KPKPN and the Commission.

KPK (Corruption Eradication Commission) was established by Act No. 30 of 2002 on the Corruption Eradication Commission. KPK is an institution that is independent and free from the influence of any power. The purpose of its formation is to improve the effectiveness of efforts at eradicating corruption, with the principle of legal certainty, transparency, accountability, public interest and proportionate.

\subsection{Development Policy Of Criminal Law In Combating Corruption Within The Framework Of Criminal Law Reform In Indonesia}

Additionally, in Act No. 31 of 1999 formulated some changes in criminal sanctions for perpetrators of corruption. In the known laws of capital punishment as contained in Article 2 paragraph (2) which reads: "In terms of corruption as referred to in paragraph (1) shall be done under certain circumstances, the death penalty may be imposed". Definition of "particular circumstances" in this provision is intended as a weighting for perpetrators of corruption if the crime was committed during a state of danger in accordance with the legislation in force, at the time of national disaster, as the repetition of corruption, or at a country in a state of economic and monetary crisis. 
With the threat of the death penalty is, Act No. 31 of 1999 is legislation that is the loudest and weight in ASEAN. ${ }^{7}$ However, in its development, this explanation declared invalid because of Act No. 20 of 2001 on the Amendment of Act No. 31 of 1999 on Corruption Eradication has formulated a new explanation of the article. Changes criminal penalty in addition to a sentence of death is good for a minimum penalty of imprisonment or a fine. The concept of minimum criminal threat is a new concept that is not recognized in the Criminal Code.

The formulation of minimum criminal sanctions there are shortcomings, ie it does not formulate sentencing guidelines to implement this minimum criminal threats. Supposedly special legislation outside the Criminal Code makes its own rules for its application, because it is a logical consequence of Article 103 of the Criminal Code.

Without this minimal criminal sentencing guidelines, it can not be determined whether the minimum punishment be commuted or be aggravated. Other irregularities appear in criminal patterns minimum. There is a criminal offense punishable by a maximum 20 years in prison and a criminal penal minimum 4 years imprisonment under Article 2 and Article 12. Meanwhile, there is a criminal offense punishable by a maximum 20 years in prison, but the minimum penalty of one year in prison as in Article 3. governed criminal offense at least 1 year shall be punishable by a maximum of five years in prison as in Article 9 and Article 11.

System concept formulation cumulative system and formulation of cumulative alternative penalty of the law that is used is not clear because the concept raises a simple question the most basic namely why the offense of corruption in the form of enrichment in Article 2 shall be sentenced to a cumulative, while abusing the authority in Article 3 shall be sentenced to a cumulative alternatives. Though both of these offenses and the same maximum penalty of weight / quality are also the same offense. It can be concluded that the legislators are still not precisely formulate criminal sanctions in corruption so natural that during the reform era of corruption is still rampant. Uncontrolled development of crime is increasing, it can be caused by incorrect use of sanctions is selected and specified. At least in the formulation of criminal laws can be a factor less precise rise and growth of criminality.

No sanction arrangements in the Presidential Decree No. 70 of 2012, contained in Article 118 paragraph (2), namely:

- Administrative sanctions.

- Sanctions inclusion in the blacklist.

- A civil lawsuit.

- Reporting crime to the authorities.

\footnotetext{
${ }^{7}$ Surachmin dan Suhandi Cahaya, 2011, Strategi Dan Teknik Korupsi: Mengetahui Untuk Mencegah, $2^{\text {nd }}$ Edition, Jakarta, Sinar Grafika, p. 73
} 
Based on the formulation of sanctions contained in this regulation, it seems that the framers embraced provisions consequentialist theory, which considers a criminal prosecution as a result of behavior that cause harm, and it is fitting offender subject to a loss in the form of criminal sanctions. In this view, the prevention of crime in the future is the main purpose of punishment. With sanctions formulated, where the crime reporting into the end seems that forming the view that the criminal rule it can bring good because it can prevent the occurrence worse and think that there is no alternative equivalent countermeasures well in these irregularities.

Corruption in Legal Studies progressive eradication of corruption is very interesting to study. The problems faced by our country is indeed require thinking intellectually as well as had been delivered in the introduction that law enforcement against corruption needs to be seen from legal theory known as progressive legal theory. This is a consideration for application of the laws is done by using the concept of law as understood in the tradition of legal thought-positivism; who view the law was limited to the circle of the legislation and interpretation of legislation formally commit-textual; by ignoring social values in society, then that will happen is the law that serve the interests of the elite, not the public interest, so that the purpose of the law of justice will be far from what is expected. If the State law (rechstaat) it has been read by actors and law enforcement as a State law and State procedures, then this country is experiencing a serious decline. Therefore, application of the law requires the existence of another legal concept, which further enable achievement of the objectives of law to achieve justice and prosperity of the people of Indonesia.

The concept of progressive law, who interpret the law to people and society and not for the benefit of himself, is an alternative that can be used in the application of the law, which is more likely to realize the purpose of law in all aspire. In the tradition of legal thought-positivism, which is widely embraced by democracies today, the law conceived as a product of legislation. Law is the legislation produced through a process of national legislation. Applicable law, solely because it has been established in the form of legislation, regardless of whether it includes the values of justice or not. In this system, the legal actors (judges and bureaucracy), as the doctrine of the analytical jurisprudence, only served as a trumpet or funnel law.

\section{Closing}

\subsection{Conclusion}

- Settings on the Crime of corruption in the procurement of goods and services defined in the Criminal Code as well as in Act Corruption today. However, there are still weaknesses contained in the Anti-Corruption Act today, one about the formulation of minimum criminal sanctions, which do not formulate sentencing guidelines to implement this minimum criminal threats. Supposedly special 
legislation outside the Criminal Code makes its own rules for its application, because it is a logical consequence of Article 103 of the Criminal Code. Formulation of corruption with the scope as defined in the 2018 Penal Code concept is sufficient to provide deterrence or prevention against corruption, especially for White Collar Crime involving state officials, including law enforcement in the future.

- Corruption that has grown and occurs systemically and widespread must be done explicitly countermeasures to combat it. Corruption need severe sanctions (the imposition of the death penalty if necessary) in addition to confiscation of the wealth gained from corruption. Cooperation of various parties must be improved so that the law enforcement process runs with orderly and appropriate procedures, so that the perpetrators of criminal sanctions in kind (so that these sanctions have a deterrent effect) and eventually become a member of the public good and useful.

- Some issues regarding the criminal system that it is still in need of repair in the future is to be considered in order to create legislation that is even better. In 2018 the concept of the Criminal Code has been no formulation of the articles related to the criminal system that specifically regulates the crime of corruption by local officials, only qualifying offense of corruption that meet the elements of the subject that is a local official.

\subsection{Suggestion}

- Need for changes to the Corruption Act so in accordance with the times that gave rise to various new modus operandi. The changes are intended to at least renew the law of corruption are now intensively. In criminal law formulation currently used the Law of Corruption had been quite effective in enforcing the law and judging trail use is quite effective in the presence of OTT imposed KPK. But still have their renewal at the legislation.

- It is expected that in the Draft Bill that now it is necessary to be truly formulated clearly because in order to amend or revise them back would be very difficult contrast to the Criminal Code in the Netherlands which was intensively carried out renewal. If there are plans did want to strengthen prevention by Parliament as part of the input is to give more powers to support institutions of the Commission such as the Ombudsman, INTRAC and across various other institutions. le, there are some who still considered rudimentary by the House Committee on Criminal Code draft as the expansion of sense gratification, the purpose of any civil servants and more. Apart from that draft Penal Code should also be designed so that a social necessity especially in fighting corruption in the future.

- Indonesia adheres to the principle of legality, which is the principle which determines that no prohibited if it is not determined in advance in the legislation. This is in line with pemiikiran that the need for changes to the Act of corruption. 
The author suggests the need for a more progressive legal approach sociological attention to the development community or to see social change will be more sensitive in making regulatory or legal representative and capture the categories of corruption.

\section{Bibliography}

[1] Ahmad Ali,2009Menguak Teori Hukum (Legal Theory) dan Teori Peradilan (Judicialprudence) Termasuk Interpretasi Undang-Undang (Legisprudence), Volume 1Pemahaman Awal, Kencana, Jakarta.

[2] Barda Nawawi Arief, 1996, Bunga Rampai Kebijakan Hukum Pidana, Citra Aditya Bhakti, Bandung

[3] Bambang Sunggono,2003, Metode Penelitian hukum, PT Raja Grafindo Persada, Jakarta

[4] Hamzah Ahmad dan Anando Santoso, Kamus Pintar Bahasa Indonesia, Fajar Mulia, Surabaya, 1996

[5] Mien Rukmini, 2006, Aspek Hukum Pidana dan Kriminologi (Sebuah Bunga Rampai), penerbit PT Alumni, Bandung

[6] Muladi dan Barda Nawawi Arief, 2010, Teori-Teori dan Kebijakan Pidana, Alumni, Bandung

[7] Muladi, 1991, "Proyeksi Hukum Pidana Materiil Indonesia Pada Masa Depan", Pidato Pengukuhan Guru Besar,: Universitas Diponegoro, Semarang

[8] P.A.F. Lamintang, 1997, Dasar-dasar Hukum Pidana di Indonesia. PT. Citra Aditya Bakti : Bandung. 